\title{
Extreme Pessimists? Expected Socioeconomic Downward Mobility and the Political Attitudes of Young Adults
}

\author{
Elena Cristina Mitrea ${ }^{1} \cdot$ Monika Mühlböck $^{2}$ D $\cdot$ Julia Warmuth $^{2}$
}

Published online: 18 January 2020

(c) The Author(s) 2020

\begin{abstract}
In recent decades, and especially since the economic crisis, young people have been finding it more difficult to maintain or exceed the living standards of their parents. As a result, they increasingly expect socioeconomic downward mobility. We study the influence of such a pessimistic view on political attitudes, assuming that it is not so much young adults' current economic status, but rather their anxiety concerning a prospective socioeconomic decline that affects their ideological positions. Drawing on data from a survey among young adults aged 18-35 in eleven European countries, we explore to what extent expected intergenerational downward mobility correlates with right-wing and left-wing self-placement. We find that young adults who expect to do worse than their parents in the future are indeed more likely to locate themselves at the extreme ends of the ideological scale.
\end{abstract}

Keywords Socioeconomic mobility $\cdot$ Intergenerational $\cdot$ European $\cdot$ Political attitudes $\cdot$ Left-right self-placement

\section{Introduction}

The promise of economic well-being achieved through meritocratic means lies at the very heart of Western liberal economies. Fueled by booming economies and a growing labor market, successive generations have been motivated by the expectation of achieving a better future than their parents through hard work and responsible

Monika Mühlböck

mo.muehlboeck@univie.ac.at

Elena Cristina Mitrea

cristina.mitrea@ulbsibiu.ro

Julia Warmuth

julia.rita.warmuth@univie.ac.at

1 Lucian Blaga University of Sibiu, Sibiu, Romania

2 University of Vienna, Vienna, Austria 
behavior. However, in recent decades and especially since the economic crisis, this goal seems to be increasingly out of reach for young adults. The experience of upward mobility has become less common, while the fear of downward mobility is no longer confined to the lower bound of the social strata, but pervades the whole society (Buchholz and Blossfeld 2012; Furedi 2002). Education has started losing currency as one of the most important drivers of social mobility, as its expected returns have changed significantly (European Commission 2015). Moreover, given its growing links to parental economic and cultural capital, education now contributes to and even exacerbates inequality, thereby blocking avenues for social mobility (Lupton et al. 2009).

Historically, recessions or periods of poor economic performance have bred a sense of economic insecurity that has translated for some sections of the population into support for the political extremes (de Bromhead et al. 2013; Funke et al. 2016; Bruckner and Grüner 2010). For example, the poorer, unemployed, or economically insecure parts of the citizenry offer a support base for the radical right (Norris 2005; Rydgren 2007). Thereby, people's political behavior and attitudes are influenced not only by their objective current financial situation, but also (and probably even more strongly) by their subjective perceptions of economic insecurity or expectations and fears about their future economic standing (cf. Geishecker and Siedler 2012).

Parties on both ends of the political spectrum have successfully capitalized on people's expectations and anxieties about the future for political gains. According to an analysis performed by the polling institute SORA on the 2017 Austrian general elections, among those who assumed that "the young generation will be worse off," $42 \%$ voted for the right-wing FPÖ, while the share of FPÖ-voters among those who were optimistic about the future amounted to only 5\% (Zandonella and Perlot 2017). A similar divide between optimists and pessimists occurred in the 2017 German federal elections, where those with negative perceptions about the future were much more likely to vote either for the AfD (Alternative für Deutschland) or Die Linke instead of centrist parties (Pokorny 2018). Recent evidence suggests that populist candidates often rely on fear-arousing campaign messages that exploit people's insecurities and uncertainty about the future (Nai 2018; Mols and Jetten 2016; Ridout and Searles 2011). Populist parties on opposite sides of the political divide use different strategies for politicizing economically rooted insecurities and grievances. Left-wing populists assign responsibility to politics, politicians and institutions, while right-wing populists point towards immigrants, refugees, minorities and cultural elites (Salmela and von Scheve 2017; Simiti 2016). Arguably, it is not so much current economic standing, but rather anxiety concerning future socioeconomic decline and déclassement, that influences electoral behavior (Flecker et al. 2007). If this assumption holds true, the growing empirical evidence indicating that status anxiety is on the rise should be alarming when it comes to tendencies of political extremism.

In this paper, we analyze how expectations of socioeconomic decline are related to political attitudes, specifically the ideological self-placement of young adults. We focus on the effect of expected intergenerational downward mobility, i.e., young adults' expectation that they will not reach the standard of living of their parents. Using survey data collected in the framework of an international and 
interdisciplinary research project on intergenerational value transmission, we find that expected intergenerational downward mobility has a significant effect on the attitudes of the youth, as those who fear socioeconomic decline are more likely to locate themselves at the extreme ends of the ideological spectrum.

We contribute to the literature on political attitudes by linking it to expected intergenerational socioeconomic mobility. The concept of expected intergenerational socioeconomic mobility has the advantage of combining a relational and a temporal component. The intergenerational comparison offers a concrete and-according to social comparison theory-highly important reference point for young adults (Diewald et al. 2015). In addition to material loss, failing to maintain the living standard of one's family implies losing connection to a group one belongs to (Erlinghagen 2008). Hence, the effect of expected intergenerational mobility on political attitudes might be even stronger than the influence of experienced intergenerational mobility, current economic status, or more diffuse expectations about the future (cf. Schuck and Shore 2019). Furthermore, our focus on young adults allows us to study the effects of expected downward mobility for a cohort that has been particularly affected by the economic downturn in the aftermath of the financial crisis of 2008 (United Nations 2012). Finally, unlike most previous studies, we do not simply test for a unidirectional effect from left to right or right to left, or for extremism (without distinguishing between left and right), but for a bidirectional effect from the center to the right and to the left. Indeed, we observe such a bidirectional effect. This bidirectionality distinguishes the effect of expectations about the future from the effect of current economic circumstances, which we find to be unidirectional.

The paper is structured as follows. We first discuss the understandings and present realities of expected intergenerational downward mobility. Subsequently, we touch upon its relevance for individuals' political attitudes and present an overview of previous literature, which has studied the links between economic insecurity or expectations about the future and political attitudes. Next, we describe the data and methods used for the analysis. Finally, we present and discuss the results of the empirical analysis.

\section{Expected Intergenerational Socioeconomic Mobility}

We define the expected intergenerational socioeconomic mobility of young adults as the individual assessment of whether they will or will not be able to reach (or surpass) their parents' standard of living (cf. Schöneck et al. 2011). As mentioned in the introduction, parents provide a highly important reference point for young adults. We use a perceptual measure rather than relying on the actual intergenerational comparison of educational levels or occupational status, as the latter suffers from two significant shortcomings when applied to young people as a target group. First, young adults who have not finished their education and entered the labor market cannot be clearly classified in comparison to their parents. Second, structural changes in the labor market as well as the education system have caused the exchange rate between educational credentials and economic capital to change (e.g. destandardization of educational pathways and school-to-work transitions have 
rendered the benefits of education in terms of career prospects less predictable). Therefore, educational and occupational intergenerational mobility may not be valid indicators of social mobility in terms of standard of living. Furthermore, assessing the expectations of how one's standard of living will develop in the future provides valuable information about how young people perceive societal challenges and the way they affect their futures and life courses.

The concept of expected intergenerational socioeconomic mobility can be distinguished from other approaches that try to capture individual perceptions with regard to future developments and social status, as none of these approaches includes the parents as a reference point. Both status anxiety (Lengfeld 2018) and subjective economic insecurity (Erlinghagen 2008) focus on intragenerational, rather than intergenerational mobility as they assess the fear of losing one's job. This conceptualization is marked by a relatively short time horizon (normally 12 month) and excludes from the analysis all those who actually have a higher propensity to be downwardly mobile (e.g. individuals who are unemployed or out of the labor force). More general concepts, such as social pessimism, defined as the concern among citizens that their society is in decline (Steenvoorden and Harteveld 2018), capture expectations about the future of a large group and are not necessarily related to individualized expectations.

Expected intergenerational socioeconomic mobility crucially shapes the lifecourse of young adults. According to the theory of relative risk aversion, decisions made during the period of education and the transition to full-time employment are mainly motivated by individuals' desire to (at least) reproduce the social status of their family of origin (Holm and Jæger 2008; van de Werfhorst and Hofstede 2007). As expected losses count more strongly than expected gains, people are more likely to take risks in order to avoid downward than to achieve upward mobility (cf. Kahnemann and Tversky 1979). Expectations regarding socioeconomic mobility also strongly affect personal well-being and attitudes towards the welfare state (Schuck and Shore 2019).

Expectations about socioeconomic mobility are affected by the surrounding economic environment, as well as by the institutional setting (e.g., national social policy measures and labor market regulations), which can mitigate the socioeconomic consequences of events that have the potential to alter an individual's standard of living (DiPrete 2002). In the aftermath of the Second World War, upward mobility had become the norm due to increased enrolment in education combined with flourishing economies in need of high skilled workers (Thijssen and Wolbers 2016). In recent years, however, it has become apparent that socioeconomic mobility is by no means unidirectional. As the 2016 State of the Nation report on social mobility in Great Britain states: "The twenteeth-century expectation was that each generation would be better off than the one preceding it, but this social mobility aspiration is no longer being met" (Social Mobility Commission 2016). Especially in Europe and in the United States, downward mobility is on the rise (Bukodi et al. 2015; Peugny 2007; Chetty et al. 2017), fostered by two main dynamics. Firstly, the occupational structure has not kept pace with educational expansion, thereby decreasing the returns of education for the younger generation. Secondly, the 2008 economic crisis has rendered the school-to-work transition more difficult, including longer 
periods of job-search and a higher likelihood of temporary contracts and low-paid jobs (European Commission 2015, p. 6).

The increased probability of socioeconomic downward mobility is reflected in people's expectations about the future, which have become more pessimistic in the wake of the crisis (Chambers et al. 2015). Due to differences in economic development and national institutional mechanisms, expectations regarding socioeconomic mobility are thus supposed to vary across countries. However, even in comparably prosperous countries like Germany, people have increasingly lost faith in the idea of collective upward mobility and pessimism about the future permeates all social strata (Schöneck et al. 2011). Overall, approximately $60 \%$ of all young people in Europe indicate that one of the greatest risk they face is not attaining the level of status and comfort that their parents had (OECD 2019; Table 1 in Appendix).

\section{The Political Consequences of Expected Downward Socioeconomic Mobility}

Previous literature on political orientations has mostly focused on the effects of existing economic conditions and experienced social mobility, rather than studying the consequences of expectations regarding future mobility. Nevertheless, past studies still offer valuable material for formulating hypotheses about the effects of expected downward mobility on left-right self-placement.

According to the new cleavage thesis, socially disadvantaged and economically insecure citizens are more susceptible to the appeals of the radical right (Norris 2005). Indeed, Funke et al. (2016) found that far-right parties were able to increase their vote share by $30 \%$ in the aftermath of financial crises. Moreover, Jackman and Volpert (1996) showed that high unemployment rates are positively correlated with electoral gains for the far right. Economic insecurity translates into support for the far-right through feelings of relative deprivation, which arise from negative comparisons drawn between actual economic well-being and one's expectations or a social reference group. Coping with such feelings increases the likelihood of rejecting political elites and nurturing anti-foreign sentiments (Elchardus and Spruyt 2012). Similarly, Burgoon et al. (2019) show that deprivation relative to the income growth among the poorest group in a country is associated with support for radical right parties.

Further studies have highlighted the importance of expectations about the future for people's political behavior and attitudes. In their seminal accounts, Bell (1955) and Lipset (1960), Daniel Bell and Seymour Martin Lipset respectively, traced support for the right to the fear of status loss among the petite bourgeoisie in industrial societies. Betz and Immerfall (1998) have argued that under conditions of recession and a poor economy, people vote for the extreme right out of fear of the future. For instance, Germans who fear the loss of their job are more likely to support far right-wing parties (Geishecker and Siedler 2012). Moreover, workers who are at a greater risk of redundancy due to labor automation turn to the radical right for protection against the threat of economic status loss (Im et al. 2019). The spectre of downward mobility has also hung over the recent American elections and Brexit vote, as the loss of confidence in and fear of the future are 
recursive features of the right-wing and populist discourse. According to Mutz (2018), support for Donald Trump in the 2016 presidential election was not rooted in the frustration of those left behind economically. Rather, Trump's success was explained by the anxiety of dominant white Americans about maintaining their high status against a background of perceived group threat from minorities.

But do economic insecurity and expectations of downward mobility necessarily lead people to the right? In their classic 1959 study, Lipset and Bendix (1959) reported that the downwardly mobile among the middle-class in the US were more likely to prefer left-wing parties than members of their origin group, but less likely than members of their destination group. Similarly, the downwardly mobile in the UK showed a shift in party preferences towards Labour (Abramson 1972). Several other studies have reported a shift in party preferences and political attitudes towards the left among the downwardly mobile, while the upwardly mobile were reported to display more conservative political attitudes (Wilensky and Edwards 1959; Abramson and Books 1971; Martinussen 1992).

A substantial amount of literature has been dedicated to economic self-interest as a mechanism for explaining shifts in people's attitudes, especially in connection to redistribution and welfare policies, as a consequence of changes in their current or expected economic standing. Studies have consistently found that low income citizens lean on average more to the left of the political spectrum and favor government intervention and more redistribution of wealth (Flavin 2012; Gilens 2009; Giger et al. 2012). Moreover, evidence shows that the experience of economic shocks, such as the loss of employment, a substantial drop in household income or a decrease in perceived employment security, increases support for redistribution (Margalit 2013). Additionally, expectations of future economic outcomes have a significant bearing on people's preferences, irrespective of their current economic standing. The Latin American experience also shows that greater pessimism about the future is often coupled with a larger demand for social security and actually moves people to the left in terms of economic issue positions (Rodrik 2001). On the other hand, individuals who expect a higher income in the future, both over a short time horizon (Barfort 2017) and over the course of their lifetime (Rueda et al. 2014) are less inclined to support redistribution. A similar direction of effect was found in the case of people who expect upward occupational mobility (Rainer and Siedler 2007).

Bénabou and Ok (2001) have put forward the "prospect of upward mobility" (POUM) hypothesis, which holds that support for redistribution is lower among those people on the lower rungs of the income ladder who expect to move up in the future. Using data from the British Household Panel Survey (BHPS), Buscha (2012) has applied the POUM hypothesis to the case of political ideology and reports that individuals who expect their financial situation to improve in a year's time are more right-wing compared to people who expect no change, whereas those who expect a deterioration are more left-wing. Furthermore, the effect of expected downward mobility on political ideology is more than twice the size of that of expected upward mobility. However, the study does not capture the intergenerational aspect of expected financial mobility, since the point of comparison used is respondents' current financial situation. 
As outlined above, the literature provides us with theoretical arguments and empirical support for downward mobility being associated with both right-wing and left-wing attitudes. On an additional theoretical level, this bidirectional effect towards both ends of the political spectrum can be explained by drawing on prospect theory (Kahnemann and Tversky 1979). Quattrone and Tversky (1988) use the fact that individuals behave in a less risk averse fashion when they have to decide between an uncertain and a (smaller) certain loss than when deciding between an uncertain and a (smaller) certain gain as an explanation for incumbents' advantage in economically prosperous times and disadvantage in times of economic downturn. In good times, voters will rather stick to what they know instead of voting for the riskier (i.e. unknown) alternative, even if the challenger candidate promises policies that would benefit these voters. In bad times, however, voters will be more likely to risk a policy change-even though they may not know exactly where it will lead them.

We argue that this mechanism should also apply to political attitudes. Extreme or radical ideological positions imply a higher risk than centrist ones and should thus be more attractive for those individuals who face losses than for those who face gains (cf. Steenbergen and Siczek 2017). Furthermore, the effect should be even more pronounced for expectations about the future than for the current economic status, as the former relate more directly to the basic principles of prospect theory. If someone expects downward mobility, s/he becomes less risk averse in trying to avoid these losses and more likely to opt for a riskier alternative-either on the left or on the right side of the political spectrum. In this paper, we will therefore test not only whether the expectation of downward mobility correlates with right-wing attitudes, but also whether it is associated with left-wing orientations.

\section{Data and Variables}

In our empirical analysis, we draw on data from a survey among young adults collected in the framework of the CUPESSE project (Tosun et al. 2019) on intergenerational (work-) value transmission. The survey was carried out in early 2016 in eleven countries, nine EU member states (Austria, Czech Republic, Denmark, Germany, Greece, Hungary, Italy, Spain and the UK) and two non-EU members (Switzerland and Turkey). A probability sample of at least 1000 young adults (aged 18 to 35) was drawn in each country, with larger samples drawn in more populous countries such as Germany, Turkey, the UK, and Spain. Focusing on young adults allowed us to ask specifically for comparisons with parents, while the age interval allowed us to cover a broad range of young people in different life-course stages between education and early career. Furthermore, the a priori restriction of the target group to young adults enabled us to draw random samples within this group, minimizing the potential of response bias (cf. Groves 2006). Nevertheless, the data comes with country-specific demographic weights according to gender, age, education, and NUTS2 region to account for any remaining selection effects. Furthermore, we use weights to account for the differences between countries in regard to the number of observations. While 
we apply these weights to all our descriptive and inferential analyses, the unweighted analysis yields highly similar results.

Our dependent variable, left-right self-placement, was measured on an 11-point scale from 0 (left) to 10 (right). The bipolar distinction between "left" and "right" has come to organize a sizeable part of the competition between parties and the political opinions of citizens, helping them simplify the complex world of politics (Fuchs and Klingemann 1990). The classic eleven-point left-right self-placement scale is widely used in surveys and is one of the most important correlates of party choice (Franklin et al. 1992; Freire 2004) and vote (Gunther and Montero 2001; Bafumi and Shapiro 2009). The left-right divide subsumes attitudes on a wide range of issues, economic (related to the role of government in the economy and the extent of redistribution) as well as social and cultural (related to the role of tradition, social and individual equality, and immigration) (Hooghe et al. 2002; Kitschelt 1994; Kriesi et al. 2006). Thus, social redistribution and social progress have become associated with the left (Bobbio 1996; Corbetta et al. 2009), while the minimal interference of the state in the economy and a defense of tradition has been related to the right (Schmitt and van der Eijk 2009; Thorisdottir et al. 2007). The recognition of the left-right concept has spilled over from political scientists to the general public, where left and right also function as symbolic labels that reflect an affective attachment to different ideological groups (Claassen et al. 2015; Devine 2015; Vegetti and Širinić 2019). Since Converse's criticism that "the liberal-conservative continuum is rather an elegant high-order abstraction and such abstractions are not typical conceptual tools for the "man in the street"' (Converse 1964, p. 215) half a century ago, the percentage of the population capable of organizing their beliefs consistently according to the definitions of left and right has increased greatly. Nevertheless, the usually high amount of refusals and thus missing values poses a potential problem with this variable. In our survey, $17.8 \%$ of the young adults did not place themselves on the scale. However, additional analysis shows that there is no relation between our main independent variable and refusal to answer the left-right self-placement question. The meaning of left and right is not invariant and has been found to be context dependent, changing across space and time (Zechmeister 2006; Benoit and Laver 2006; Thorisdottir et al. 2007). To control for potential country-specific differences, we therefore also perform within-country analyses, thereby accounting for potential country-specific differences in response styles (see Fig. 2 and Table 3 in Appendix).

The main independent variable, expected intergenerational socioeconomic downward mobility, was measured based on a survey question retrieved from the 2011 German Socio-Economic Panel (Schöneck et al. 2011), worded as follows: "Thinking about how your standard of living will be like in the future, how does it compare to how your parents are doing today?" The item was measured on a 5-point scale with answer categories running from "much worse than my parents" to "much better than my parents."

The current economic situation-our main control variable-was measured in two different ways. First, we used an index composed of different items concerning economic self-sufficiency (ability to pay one's bills, afford extras, afford decent housing, put money in a savings account), and second, we measured satisfaction with the financial situation. In the analysis presented here, only the latter measure is 
used, as it showed the strongest effect on the left-right self-placement. Additionally, it offers a subjective assessment of current economic circumstances and thus constitutes a better control variable for expected downward mobility, which is a subjective measure. In any case, the two variables are highly correlated and results do not change substantially when including one or the other.

Factors such as education, gender, age, income, employment status, religiosity, and urban/rural dwelling are significant predictors of left-right self-placement (Freire 2006; Fuchs and Klingemann 1990). People with a high level of education, women, young people, the unemployed, the non-religious, and urban residents have been found to be more supportive of the left (Gerber et al. 2010; Emmenegger and Manow 2014; Inglehart and Norris 2003). ${ }^{1}$ Support for the right has been found to be higher among people with a low level of education, men, older individuals, those who identify with a confession and are frequent churchgoers (regardless of the specific religious denomination), and rural residents (Inglehart and Klingemann 1976; Budge et al. 2010). Therefore, we further control for education (in three categories, where "low" equals ISCED I+II, "medium" equals ISCED III + IV, and "high" equals ISCED V), gender, age, occupational status (in education, working, not working/unemployed), religion (coded 1 if belonging to a religion or denomination and 0 otherwise), and population density of the NUTS2 area in which the individual lives (as a proxy for the urban-rural cleavage). ${ }^{2}$ Moreover, we include country fixed effects. Descriptive statistics of all variables are provided in Table 2 in Appendix.

\section{Analysis}

We start our analysis ${ }^{3}$ by looking at the distribution of expected downward mobility within and across countries. As shown in Fig. 1, the majority of respondents still believe in upward mobility. As expected, the share of young adults who expect downward mobility is the highest in those countries that were hit hardest by the 2008 economic crisis, namely Greece (28\%), Italy (22\%), and Spain (22\%). The fourth place is occupied by the UK $(18 \%)$, which might at first seem surprising. ${ }^{4}$ However, considering that housing prices and rent have sky-rocketed in the last decades in the $\mathrm{UK}^{5}$ while salaries have stagnated, it becomes evident why many expect the (affordable) standard of living to decline in the future. Downward mobility is expected to a much smaller degree in countries like Germany, Austria, Denmark, Switzerland, and the Czech Republic (9-14\%). The share of expected downward mobility is even lower in Hungary (5\%) and Turkey (5\%). The overwhelming majority in these two

\footnotetext{
${ }^{1}$ However, regarding the effect of age, different results have been obtained for Italy (Corbetta et al. 2013, pp. 11-32).

2 Data source: Eurostat, variables pjangroup and d3area for 2015.

3 Replication material for the analysis can be found at https://doi.org/10.7910/DVN/VA3N1L.

4 The survey was carried out before the Brexit vote and can therefore not have been influenced by its outcome.

5 The housing problem in the UK is perceived to be even worse than in Spain, a country known for its housing price bubble (Niemietz 2012; House of Commons 2015).
} 


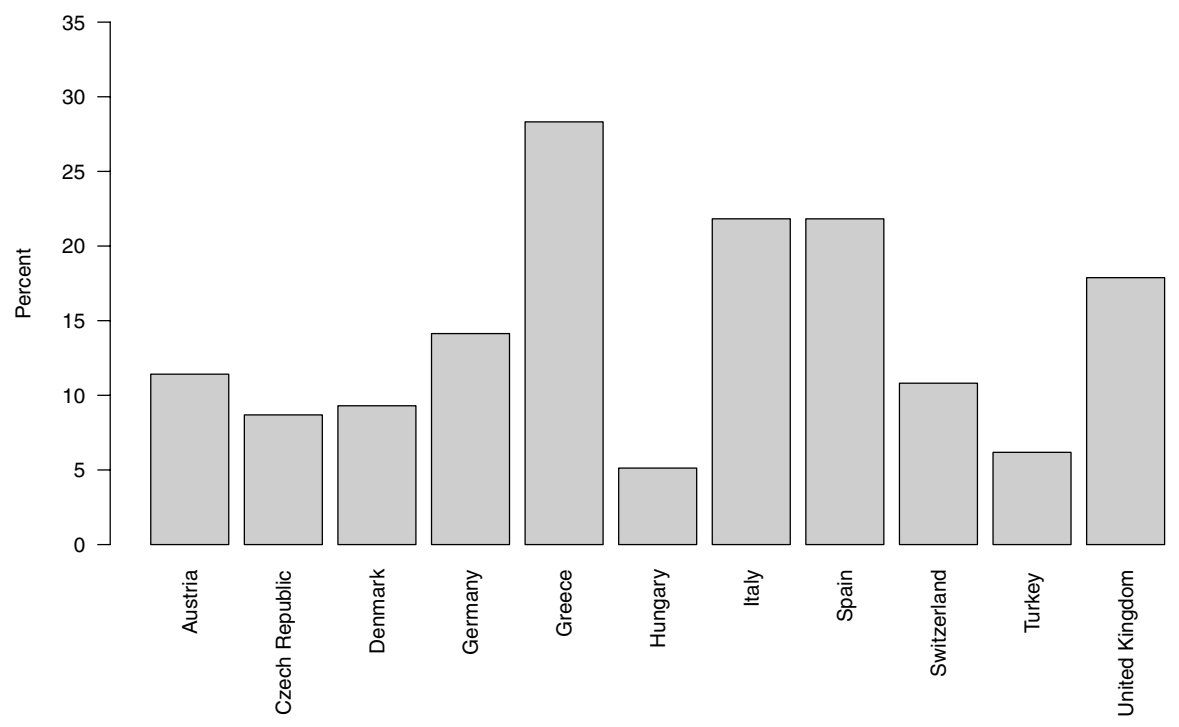

Fig. 1 Expected downward mobility among young adults. Demographic weights applied

countries still believes that their standard of living will increase in comparison to that of their parents.

These descriptive results show that expected downward mobility is widespread particularly in countries that have faced economic difficulties in recent years. We now move on to ascertain its effect on left-right self-placement. Figure 2 displays the differences in the distributions of answers to the question on left-right selfplacement between those individuals who do and those who do not expect to experience intergenerational downward mobility. The density plot for all countries shows that those who expect downward mobility (displayed by the black line) were more likely to place themselves on the far left end of the left-right spectrum than those who were more optimistic about the future (grey line). Looking at the plots for the individual countries, however, we can observe some differences. While in most of the countries (e.g. Italy, Spain, Turkey, and the UK) the shift to the left is stronger than the shift to the right, in other countries (Germany, Czech Republic, and Switzerland) those young adults who fear downward mobility place themselves more often on either extreme of the spectrum than those who are more optimistic about the future. Only in one of the countries (Austria), does the shift to the right seem to be more pronounced than the shift to the left.

The initial results are in line with the hypothesis that those who fear social decline would lean more to the extremes of the political spectrum than those who are optimistic about the future. Moreover, the shift from the center to the left seems to be more pronounced than the shift from the center to the right. In the following regression analysis, we will test whether these initial results hold true when controlling for other potentially influential factors.

Our hypothesis does not stipulate a simple linear effect of expected downward mobility on left-right self-placement. Instead of presuming expected downward 

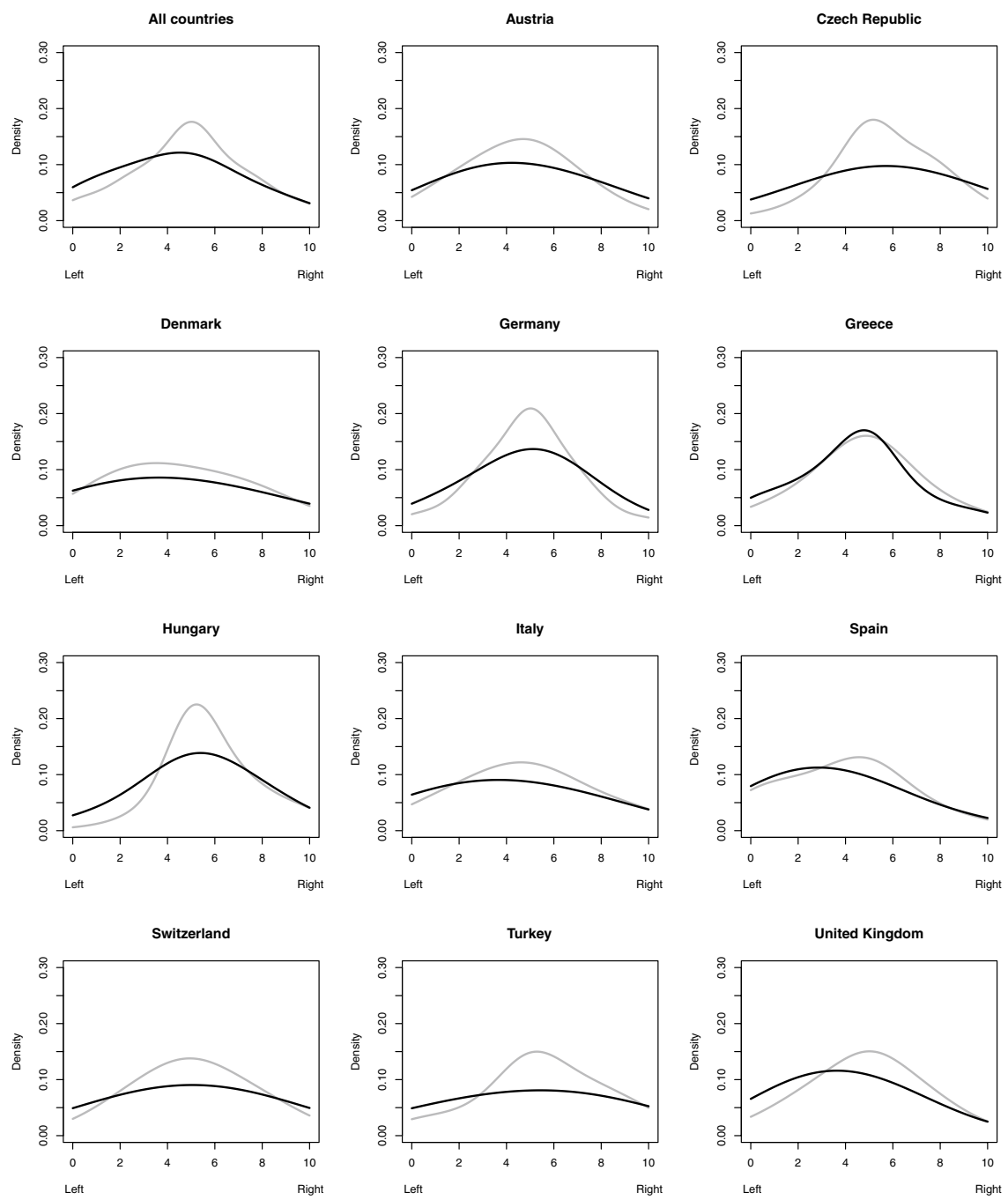

Fig. 2 Density plots of left-right self-placement for those young adults who do expect downward mobility (black lines) and who do not (grey lines). Demographic weights applied

mobility to induce a general one-directional trend (either from the right to the left or from the left to the right), we assume a bidirectional effect with expected downward mobility leading people more generally from the center to the extreme ends of the left-right spectrum. However, we are not only interested in whether individuals display more extreme positions, but also in whether they are likely to do so at the right or at the left side of the political spectrum - or both. This cannot be tested simultaneously with an OLS model. A simple OLS model with the left-right position as the dependent variable would not be suitable, as this can only reveal unidirectional effects, while bidirectional effects might cancel each other out, to show 
either no overall effect or just the direction in which the bidirectional effect points more strongly. At the same time, using the distance from the centrist position as the dependent variable would only allow us to look at extremism, but not to distinguish between left and right (nevertheless, the results of such a model are provided in Table 4 in Appendix for reference). Thus, in our main models, we employ multinomial logistic regression models with a dependent variable of three categories: extreme left, centrist, and extreme right. Thereby, the original 0-10 left-right scale was recoded into three categories: "extreme left" (0-2), "centrist" (3-7), and "extreme right" (8-10), as in Visser et al. (2014). ${ }^{6}$ We are aware of the fact that in a political context, the term "extremism" is normatively loaded. Therefore, it is necessary to stress that "extreme" in this instance does not imply radical behavior, but simply that someone has located himself or herself close to the left or the right end of the political spectrum.

Table 1 shows the results of the multinomial regression models with the left-right self-placement (in three categories) of young adults as the dependent variable. We use "centrist" as the reference category to be able to test whether those who expect downward mobility are significantly more likely to place themselves to the left or to the right of the center (or both). We control for gender, education, age, occupational status, religion, population density within the region, and satisfaction with the current financial situation. The two coefficients of "expected downward mobility" are both positive and significant, thereby indicating support for our hypothesis. However, the coefficient of the effect towards "extreme right" is smaller with a higher standard error, indicating more uncertainty concerning this result. Computing the marginal effects of the model in Table 1 shows that-keeping everything else constant-expected downward mobility raises the probability that young adults locate themselves on the left side of the political spectrum on average by about 7 percentage points (from 17 to $24 \%$ ) and the probability that they locate themselves on the right side of the political spectrum by 3 percentage points (from 15 to $18 \%$ ).

We further observe an interesting effect of "financial situation." The more satisfied respondents are with their current economic situation, the more likely they are to place themselves to the right and the less likely to place themselves to the left. The result can be replicated when using the more objective indicator for the current economic situation discussed in the last section (see Table 7 in Appendix). This indicates that while there is indeed a bidirectional effect for expected downward mobility, the effect of the current economic situation is unidirectional.

The other control variables display the expected effects. Women are more likely to place themselves to the left. Higher education is associated with more leftist positions. Students place themselves more to the left than to the right when compared to those who are working. Finally, religion plays an important role concerning political

\footnotetext{
${ }^{6}$ Using different cut-off points for the dependent variable does not change the results (see Table 5 in Appendix). Furthermore, results do not change when we use a standardized measure (a difference of more than one standard deviation from the country mean) as the dependent variable (see Table 6 in Appendix).
} 


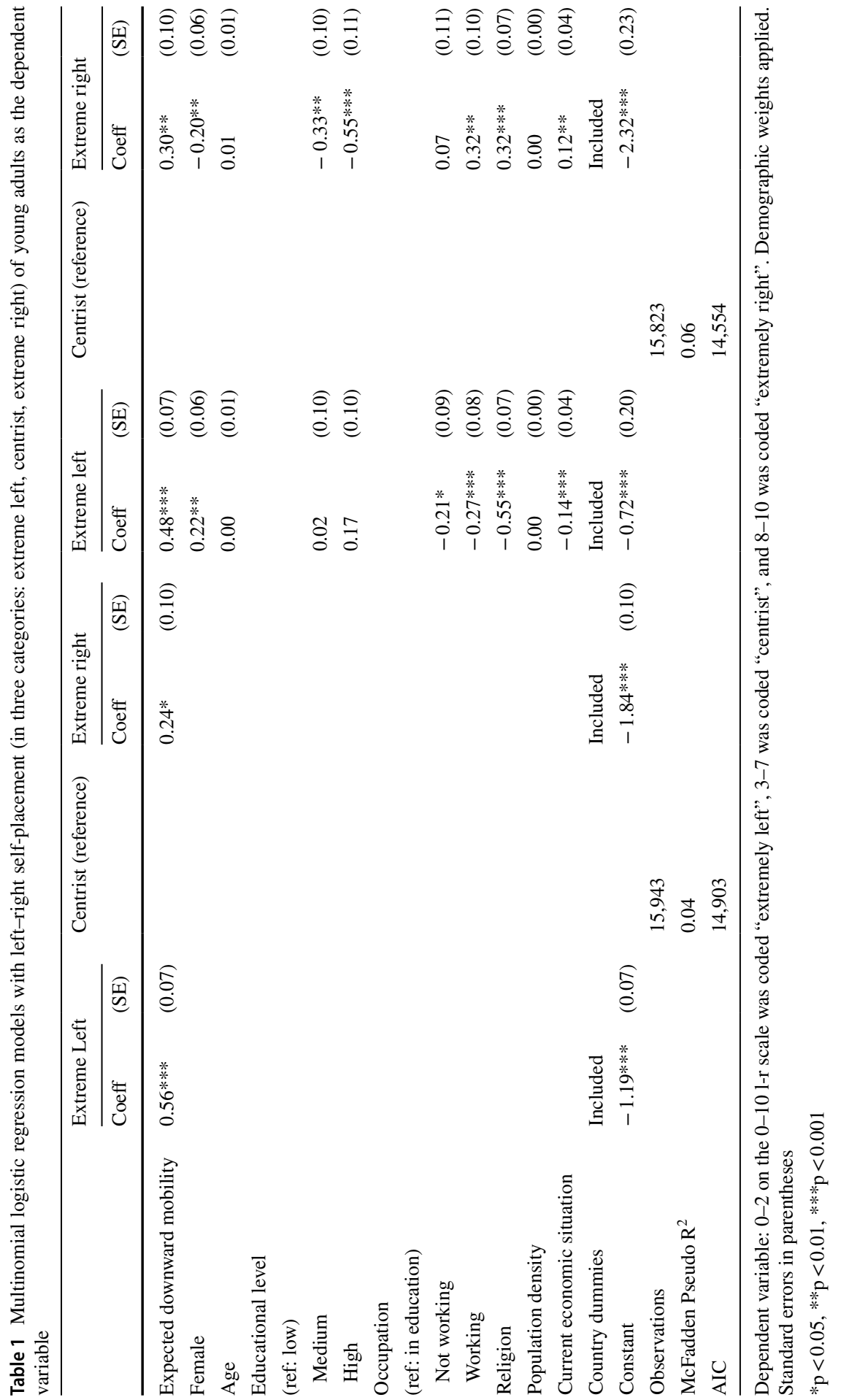


attitudes: those who do not belong to any religion or denomination are more likely to be found on the left side of the continuum. Population density-our proxy on the urban-rural cleavage-does not show any significant effect once education or religion are added as predictors.

\section{Conclusion}

Motivated by the growing anxiety about the future of the young generation in the wake of the economic crisis, we analyzed how expectations concerning downward intergenerational socioeconomic mobility affect the political attitudes of young adults. Specifically, we focused on young adults' expectations of reaching their parents' standard of living, and how these assessments affect their self-placement on a left-right ideology scale. Based on previous research that offers evidence for both a rightward and a leftward effect of economic insecurity and anxiety about the future, as well as the premises of prospect theory, which suggests that pessimistic expectations might result in more radical political attitudes and behavior, we tested whether there was a bidirectional effect of expected downward mobility on left-right self-placement.

Drawing on data from a survey of young adults in eleven European countries conducted in 2016, we found expected intergenerational mobility to vary considerably between countries. The highest shares of young adults expecting downward mobility was found in those countries that were most severely affected by the economic crisis (Greece, Italy and Spain), followed closely, however, by the UK. Moreover, we found that young adults who expected downward mobility were more likely to locate themselves at the extreme ends of the left-right spectrum. Overall, young adults who were pessimistic about the future were significantly more likely to hold leftwing positions than to place themselves in the center. At the same time, those who expected downward mobility were also more likely to hold right-wing than centrist positions. The rightward effect was less pronounced than the leftward effect. Nevertheless, the analysis shows that the effect of expected downward mobility is indeed bidirectional, in contrast to the effect of the current economic situation, which was found to be unidirectional, with a lower economic status leading to more leftist political attitudes.

While our results pertain to young adults aged $18-35$, they may similarly hold for older individuals. However, the time horizon for the outlook towards the future may of course be shorter, and the intergenerational comparison a different one, inducing the need for a modified operationalization of expected downward mobility. Furthermore, previous experiences during the life-cycle may affect expectations about the future more strongly for older individuals than for young adults.

When extrapolating from political attitudes to voting behavior, our empirical results can offer some explanations for electoral results, such as the British general elections of June 2017, where the Labour leader Jeremy Corbyn garnered surprisingly strong support-especially among young voters - with a decidedly leftist 
electoral manifesto. Likewise, the support for Bernie Sanders in the US primaries in 2016 or for Jean-Luc Mélenchon, as well as Marine Le Pen in the 2017 French presidential election may be partly explained by fears of downward mobility in the electorate, especially among the youth. The different responses to expectations of socioeconomic decline could also explain the rise of new parties on both ends of the political spectrum in the wake of the economic crisis in Greece, namely Syriza on the left, the Independent Greeks on the right, and the Golden Dawn on the far right. Our results further suggest that in conditions of increased concerns about the future, left-wing parties stand to gain the most support, if they manage to successfully mobilize voters on this issue.

However, it should be mentioned that it is impossible to completely disentangle left-right self-placement, party preferences, and voting behavior. While the underlying components of left-right attitudes may influence party choice, the party chosen and its assumed position in the policy space might also define one's self-placement. Hence, the observed strength and direction of the effects in the individual countries may also depend on whether left-wing or right-wing parties (or both) successfully mobilize young adults who fear socioeconomic decline.

We hope that this study will provide a starting point for more detailed future analyses of the political consequences of expectations of intergenerational downward mobility. Such an analysis could look more closely into country differences and results for individual countries, distinguish between economic and cultural issue positions, examine the effects for older individuals, and explore the connection between political attitudes and party preferences. Future research should also study the mechanisms behind the correlation between fear of downward mobility and extreme policy positions among young adults, as it is particularly interesting that despite having similarly negative assessments of their future, these people are turning to highly different political solutions.

Acknowledgements Open access funding provided by University of Vienna. Data collection and work on the article have been carried out as part of the CUPESSE project, which received funding from the European Union's Seventh Framework Programme for research, technological development and demonstration under Grant Agreement No 613257. The authors would like to thank the CUPESSE team, the participants in the research colloquium of the Department of Government at the University of Vienna, and the anonymous reviewers for helpful comments on previous versions of the article.

Open Access This article is licensed under a Creative Commons Attribution 4.0 International License, which permits use, sharing, adaptation, distribution and reproduction in any medium or format, as long as you give appropriate credit to the original author(s) and the source, provide a link to the Creative Commons licence, and indicate if changes were made. The images or other third party material in this article are included in the article's Creative Commons licence, unless indicated otherwise in a credit line to the material. If material is not included in the article's Creative Commons licence and your intended use is not permitted by statutory regulation or exceeds the permitted use, you will need to obtain permission directly from the copyright holder. To view a copy of this licence, visit http://creativecommons.org/licen ses/by/4.0/. 


\section{Appendix}

See Tables 2, 3, 4, 5, 6, 7.

Table 2 Descriptive statistics

\begin{tabular}{llllll}
\hline & Mean & SD & Min & Max & Obs \\
\hline $\begin{array}{l}\text { Left-right self-placement } \\
\text { Left-right self-placement }\end{array}$ & 4.85 & 2.51 & 0 & 10 & 16,447 \\
$\quad$ Centrist & & & & & 16,447 \\
Extreme left & 0.66 & & 0 & 1 & \\
Extreme right & 0.18 & & 0 & 1 & \\
Expected downward mobility & 0.16 & & 0 & 1 & \\
Female & 0.14 & & 0 & 1 & 19,507 \\
Age & 0.50 & & 0 & 1 & 20,008 \\
Educational level & 26.86 & 5.12 & 18 & 35 & 20,006 \\
$\quad$ Low & & & & & 19,875 \\
Medium & 0.20 & & 0 & 1 & \\
$\quad$ High & 0.50 & & 0 & 1 & \\
Occupation & 0.30 & & 0 & 1 & \\
In education/training & & & & & 20,003 \\
$\quad$ Not working & 0.22 & & 0 & 1 & \\
$\quad$ Working & 0.22 & & 0 & 1 & \\
Religion & 0.56 & & 0 & 1 & \\
Population density (people/km ${ }^{2}$ ) & 0.43 & & 0 & 1 & 19,845 \\
Current economic situation & 598 & 1,280 & 12 & 10,885 & 19,926 \\
Current economic self-sufficiency & 1.43 & 0.84 & 0 & 3 & 19,967 \\
\hline
\end{tabular}

Demographic weights applied 


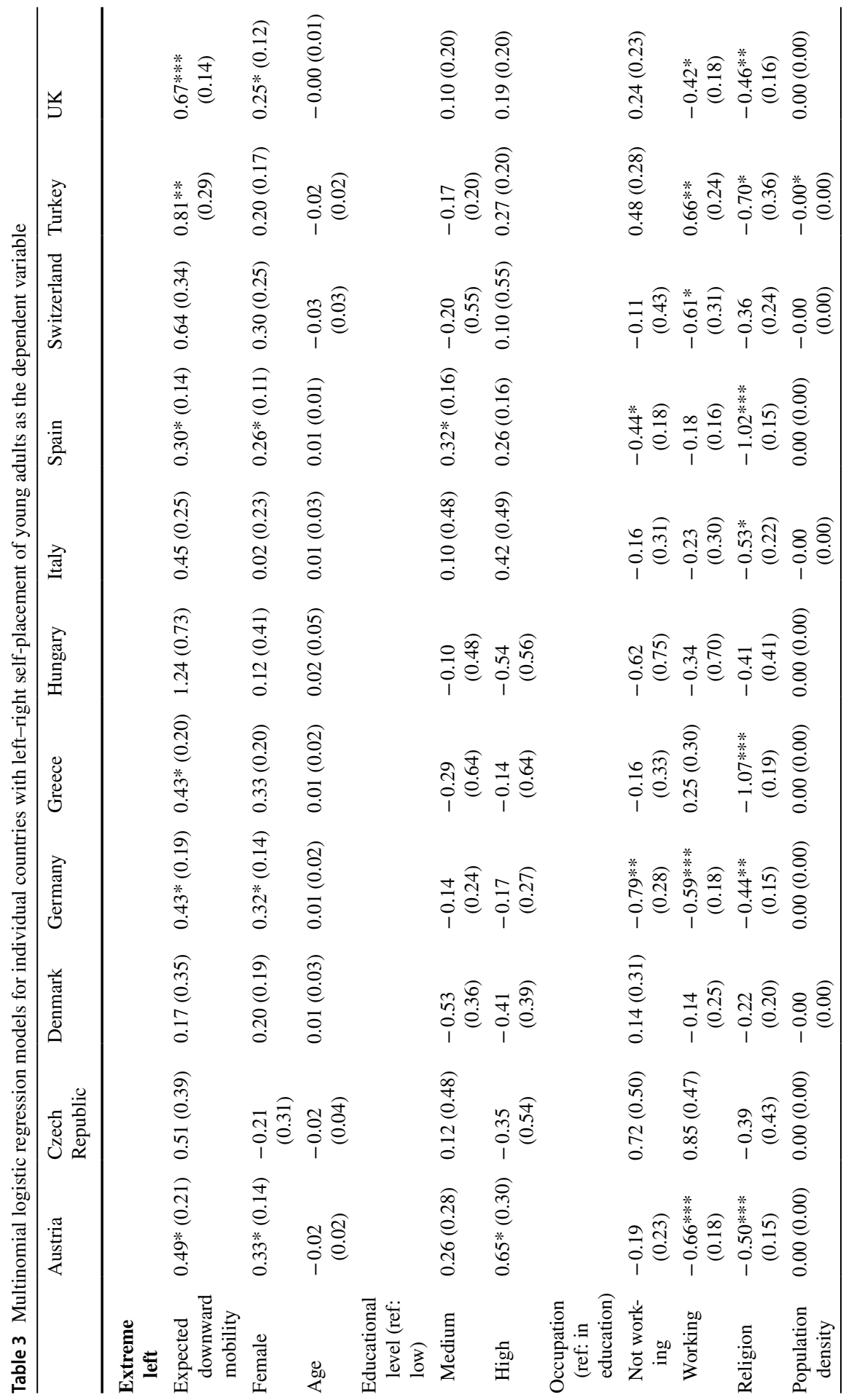




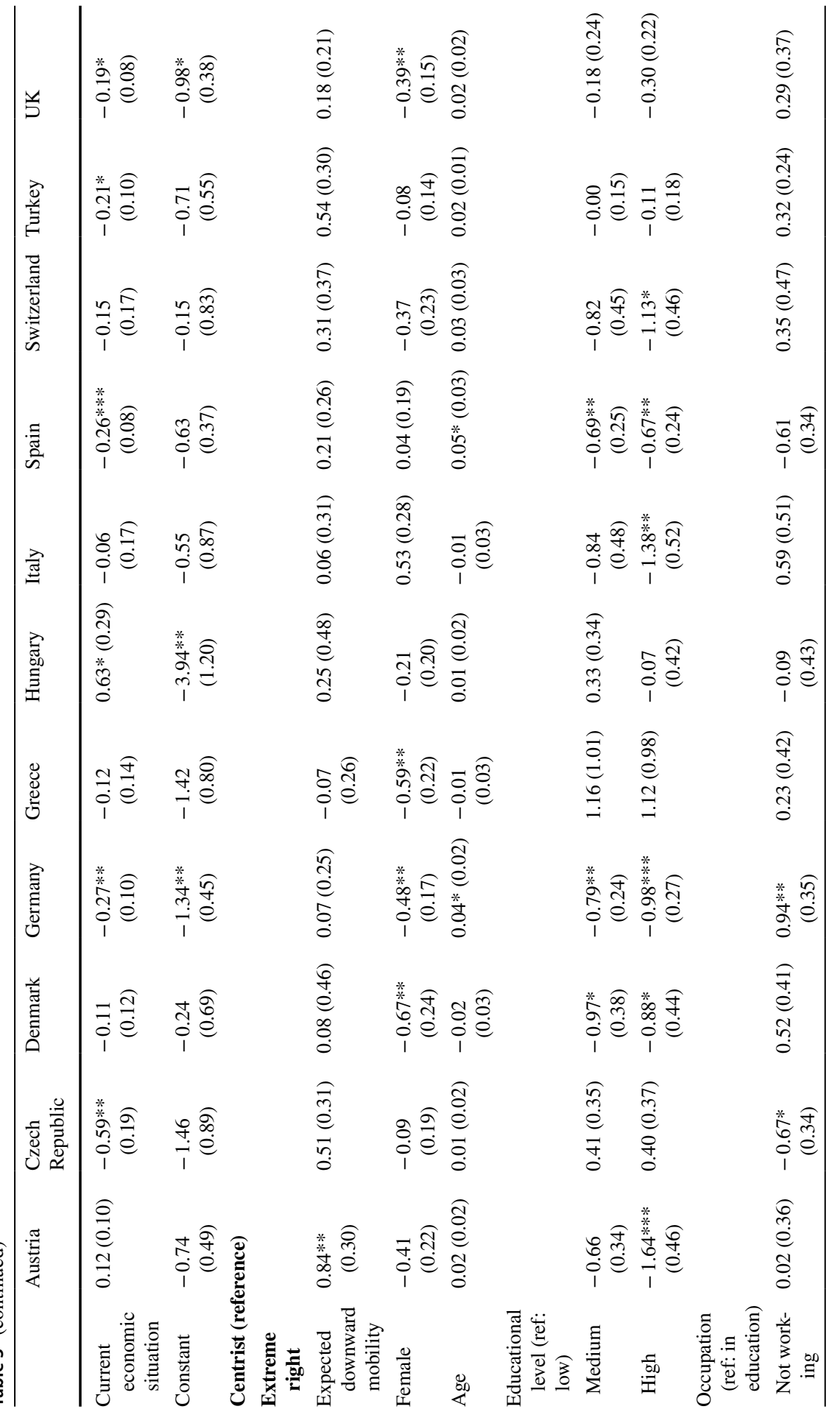




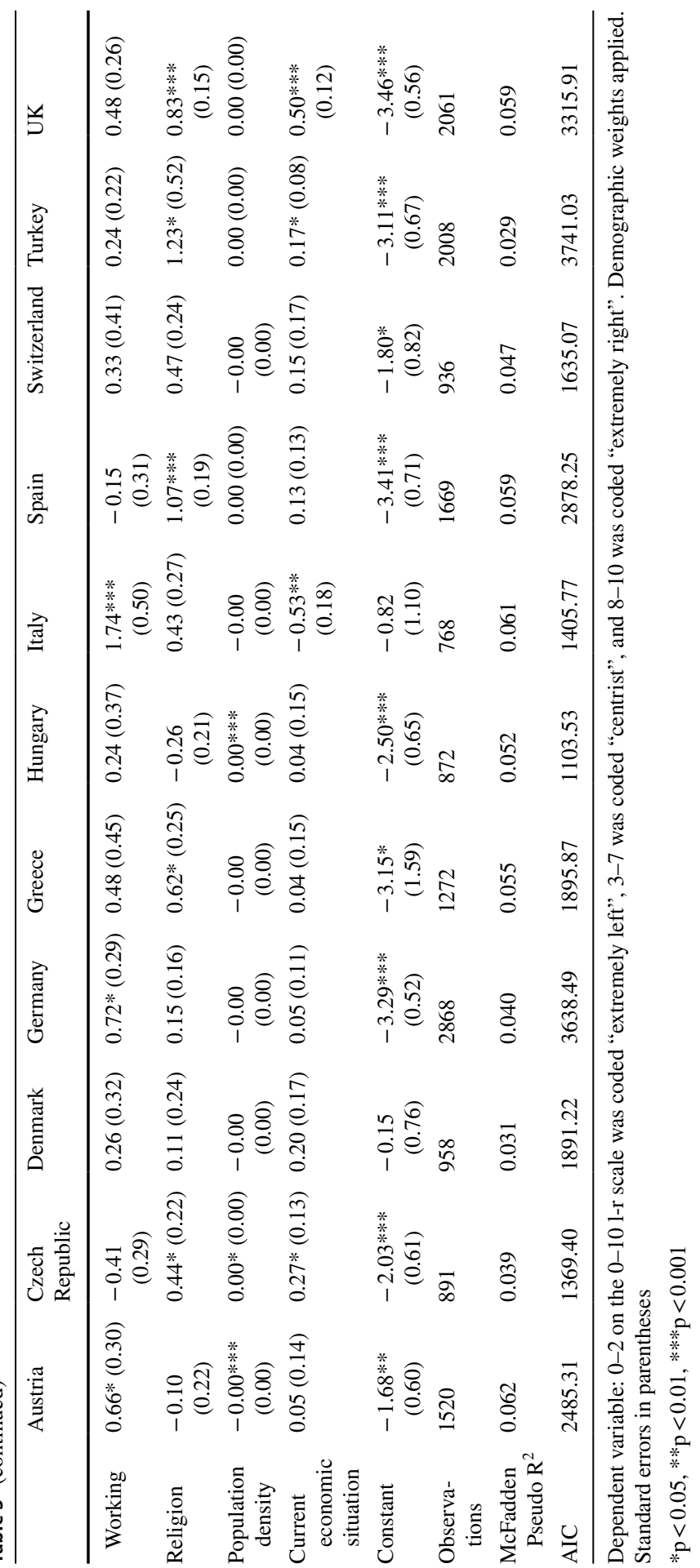


Table 4 OLS regression models with extremism in left-right self-placement (absolute difference to the center of the 1-r scale) of young adults as the dependent variable

\begin{tabular}{|c|c|c|c|c|}
\hline & \multicolumn{2}{|l|}{ M1 } & \multicolumn{2}{|l|}{ M2 } \\
\hline & Coeff & (SE) & Coeff & $(\mathrm{SE})$ \\
\hline Expected downward mobility & $0.40^{* * *}$ & $(0.05)$ & $0.37 * * *$ & $(0.05)$ \\
\hline Female & & & -0.03 & $(0.03)$ \\
\hline Age & & & 0.00 & $(0.00)$ \\
\hline \multicolumn{5}{|l|}{ Educational level (ref: low) } \\
\hline Medium & & & 0.06 & $(0.06)$ \\
\hline High & & & 0.06 & $(0.06)$ \\
\hline \multicolumn{5}{|l|}{ Occupation (ref: in education) } \\
\hline Not working & & & -0.06 & $(0.06)$ \\
\hline Working & & & 0.03 & $(0.05)$ \\
\hline Religion & & & $-0.12 * * *$ & $(0.04)$ \\
\hline Population density & & & $0.00 *$ & $(0.00)$ \\
\hline Current economic situation & & & -0.04 & $(0.02)$ \\
\hline Country dummies & Included & & Included & \\
\hline Constant & $-1.84 * * *$ & $(0.05)$ & $1.90 * * *$ & $(0.12)$ \\
\hline Observations & & 15,943 & & 15,823 \\
\hline Adj. $R^{2}$ & & 0.04 & & 0.05 \\
\hline
\end{tabular}

Demographic weights applied. Standard errors in parentheses

$* \mathrm{p}<0.05, * * \mathrm{p}<0.01, * * * \mathrm{p}<0.001$ 


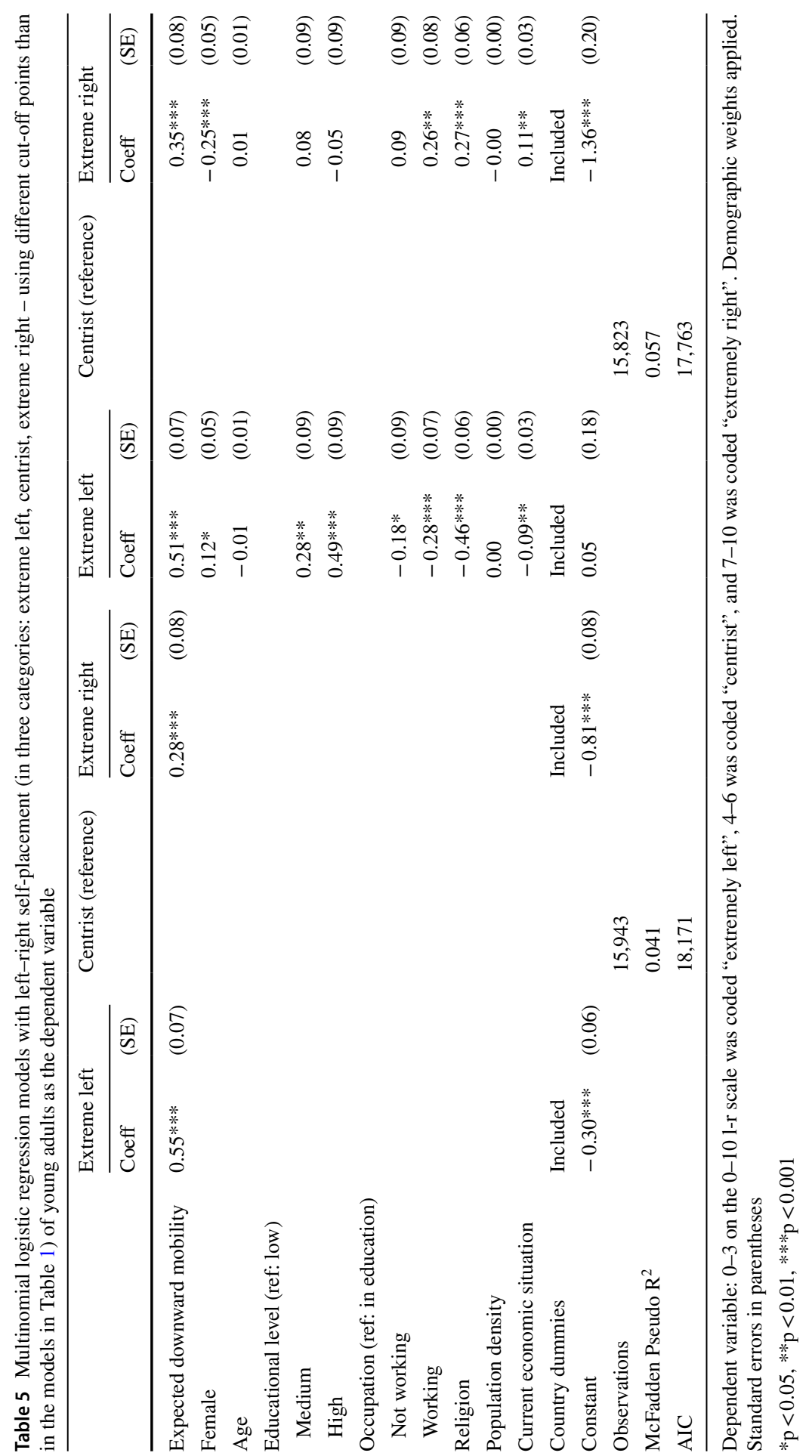




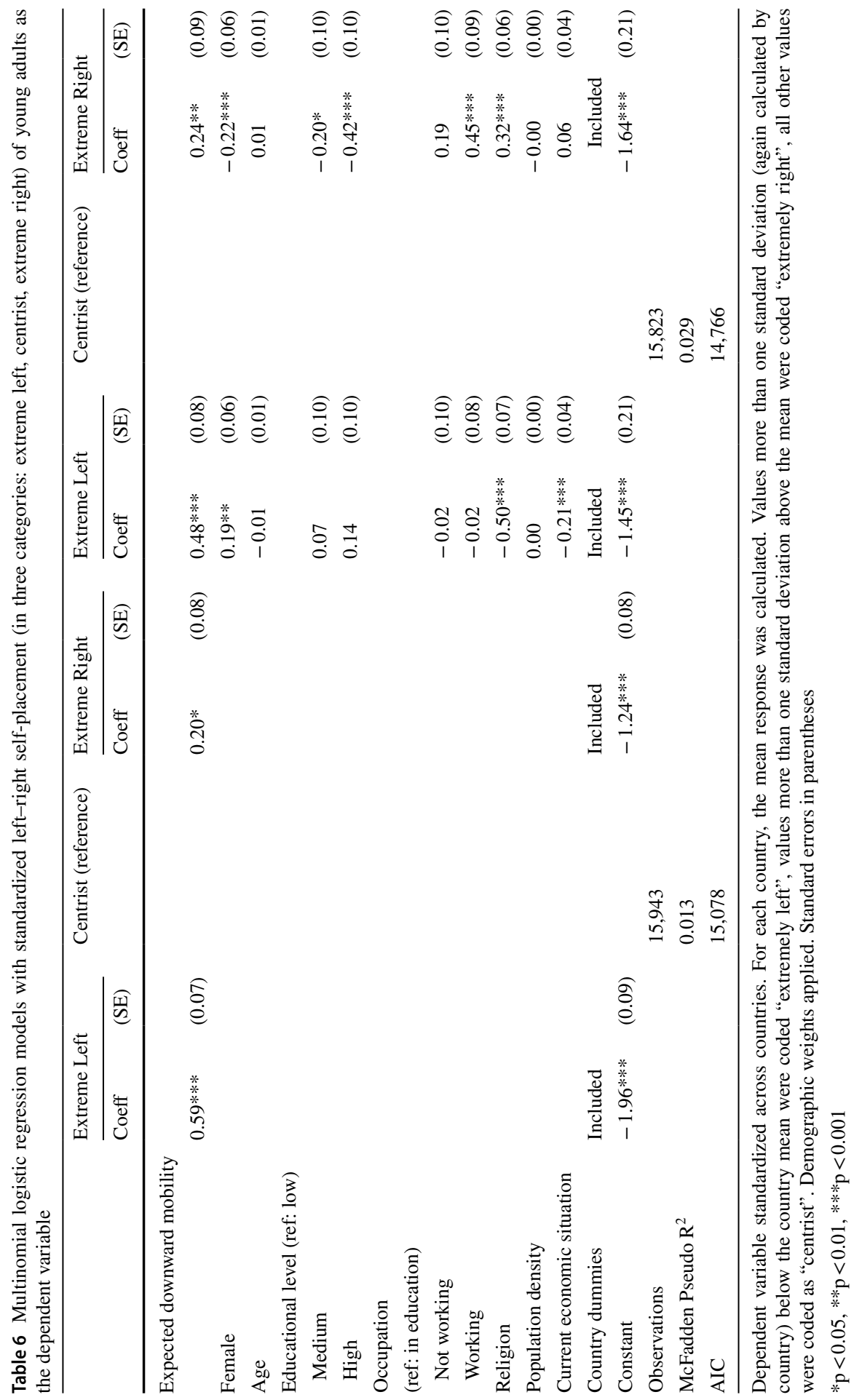


Table 7 Multinomial logistic regression models with left-right self-placement (in three categories: extreme left, centrist, extreme right) of young adults as the dependent variable and an index for economic self-sufficiency instead of the satisfaction with the current economic situation as the main control variable

\begin{tabular}{|c|c|c|c|c|c|}
\hline & Extreme left & & Centrist (reference) & Extreme right & \\
\hline & Coeff & $(\mathrm{SE})$ & & Coeff & $(\mathrm{SE})$ \\
\hline Expected downward mobility & $0.46^{* * *} *$ & $(0.07)$ & & $0.33 * * *$ & $(0.10)$ \\
\hline Female & $0.21 * * *$ & $(0.06)$ & & $-0.19 * *$ & $(0.06)$ \\
\hline Age & -0.00 & $(0.01)$ & & 0.01 & $(0.01)$ \\
\hline \multicolumn{6}{|l|}{ Educational level (ref: low) } \\
\hline Medium & 0.03 & $(0.10)$ & & $-0.35^{* * *}$ & $(0.10)$ \\
\hline High & 0.20 & $(0.10)$ & & $-0.58 * * *$ & $(0.11)$ \\
\hline \multicolumn{6}{|l|}{ Occupation (ref: in education) } \\
\hline Not working & $-0.21 *$ & $(0.09)$ & & 0.06 & $(0.12)$ \\
\hline Working & $-0.26^{* *}$ & $(0.08)$ & & $0.29 * *$ & $(0.10)$ \\
\hline Religion & $-0.56^{* * *}$ & $(0.07)$ & & $0.32 * * *$ & $(0.07)$ \\
\hline Population density & 0.00 & $(0.00)$ & & 0.00 & $(0.00)$ \\
\hline Current economic self-sufficiency & $-0.15^{* * *}$ & $(0.04)$ & & $0.18 * * *$ & $(0.04)$ \\
\hline Country dummies & Included & & & Included & \\
\hline Constant & $-0.59 * *$ & $(0.21)$ & & $-2.62 * * *$ & $(0.25)$ \\
\hline Observations & & & 15,708 & & \\
\hline McFadden Pseudo $\mathrm{R}^{2}$ & & & 0.062 & & \\
\hline AIC & & & 14,418 & & \\
\hline
\end{tabular}

Dependent variable: 0-2 on the 0-10 1-r scale was coded "extremely left", 3-7 was coded "centrist", and 8-10 was coded "extremely right". Demographic weights applied. Standard errors in parentheses

$* \mathrm{p}<0.05, * * \mathrm{p}<0.01, * * * \mathrm{p}<0.001$

\section{References}

Abramson, P. R. (1972). Intergenerational social mobility and partisan choice. American Political Science Review, 66(4), 1291-1294.

Abramson, P. R., \& Books, J. W. (1971). Social mobility and political attitudes: A study of intergenerational mobility among young British men. Comparative Politics, 3(3), 403-428.

Bafumi, J., \& Shapiro, R. Y. (2009). A new partisan voter. The Journal of Politics, 71(1), 1-24.

Barfort, S. (2017). The effect of income expectations on social policy preferences. Working Paper. London School of Economics and Political Science. Retrieved September 18, 2019, from https://sebas tianbarfort.github.io/papers/barfort2017expectations.pdf.

Bell, D. (1955). The new American right. New York: Criterion Books.

Bénabou, R., \& Ok, E. A. (2001). Social mobility and the demand for redistribution: The POUM hypothesis. The Quarterly Journal of Economics, 116(2), 447-487.

Benoit, K., \& Laver, M. (2006). Party policy in modern democracies. London: Routledge.

Betz, H.-G., \& Immerfall, S. (1998). The new politics of the right. Neo-populist parties and movements in established democracies. New York: St. Martin's Press.

Bobbio, N. (1996). Left and right: The significance of a political distinction. Chicago: University of Chicago Press.

Bruckner, M. \& Grüner, H. P. (2010). Economic growth and the rise of political extremism: Theory and evidence. CEPR Discussion Papers 7723, C.E.P.R. Discussion Papers. Retrieved September 9, 2019, from https://papers.ssrn.com/sol3/papers.cfm?abstract_id=1573427. 
Buchholz, S., \& Blossfeld, H. P. (2012). Changes in the economy, the labor market, and expectations for the future: What might Europe and the United States look like in twenty-five years? New Directions for Youth Development, 135, 17-25.

Budge, I., Crewe, I., \& Farlie, D. (2010). Party identification and beyond: Representations of voting and party competition. Colchester: ECPR Press.

Bukodi, E., Goldthorpe, J. H., Waller, L., \& Kuha, J. (2015). The mobility problem in Britain: New findings from the analysis of birth cohort data. British Journal of Sociology, 66(1), 93-117.

Burgoon, B., van Noort, S., Rooduijn, M., \& Underhill, G. (2019). Positional deprivation and support for radical right and radical left parties. Economic Policy, 34(97), 49-93.

Buscha, F. (2012). Financial expectation and the "left-right" political value scale: Testing the POUM hypothesis. Economic Letters, 115(3), 460-464.

Chambers, J. R., Swan, L. K., \& Heesacker, M. (2015). Perceptions of U.S. social mobility are divided (and distorted) along Ideological lines. Psychological Science, 26(4), 413-423.

Chetty, R., Grusky, D., Hell, M., Hendren, N., Manducca, R., \& Narang, J. (2017). The fading American dream: Trends in absolute income mobility since 1940. Science, 365(6336), 398-406.

Claassen, C., Tucker, P., \& Smith, S. S. (2015). Ideological labels in America. Political Behavior, 37(2), 253-278.

Converse, P. E. (1964). The nature of belief systems in mass publics. In D. E. Apter (Ed.), Ideology and discontent (pp. 206-261). London: Free Press of Glencoe.

Corbetta, P., Cavazza, N., \& Roccato, M. (2009). Between ideology and social representations: Four theses plus (a new) one on the relevance and the meaning of the political left and right. European Journal of Political Research, 48(5), 622-641.

Corbetta, P., Tuorto, D., \& Cavazza, N. (2013). Parents and children in the political socialisation process: Changes in Italy over thirty-five years. Essex, UK: ECPR Press.

de Bromhead, A., Eichengreen, B., \& O’Rourke, K. H. (1930s). Political extremism in the 1920s and 1930s: Do German lessons generalize? The Journal of Economic History, 73(2), 371-406.

Devine, C. J. (2015). Ideological social identity: Psychological attachment to ideological in-groups as a political phenomenon and a behavioral influence. Political Behavior, 37(3), 509-535.

Diewald, M., Schulz, W., \& Baier, T. (2015). Intergenerational downward mobility in educational attainment and occupational careers in West Germany in the twentieth century. European Sociological Review, 31(2), 172-183.

DiPrete, T. A. (2002). Life course risks, mobility regimes, and mobility consequences: A comparison of Sweden, Germany, and the United States. American Journal of Sociology, 108(2), 267-309.

Elchardus, M., \& Spruyt, B. (2012). The contemporary contradictions of egalitarianism: An empirical analysis of the relationship between the old and new left/right alignments. European Political Science Review, 4(2), 217-239.

Emmenegger, P., \& Manow, P. (1970s). Religion and the gender vote gap: Women's changed political preferences from the 1970s to 2010. Politics \& Society, 42(2), 166-193.

Erlinghagen, M. (2008). Self-perceived job insecurity and social context: A multi-level analysis of 17 European countries. European Sociological Review, 24(2), 183-197.

European Commission (2015). Their future is our future: Youth as actors of change. Directorate-General for Research and Innovation Inclusive, Innovative and Reflective Societies. Retrieved September 9, 2019, from https://ec.europa.eu/research/social-sciences/pdf/project_synopses/kina27205enc.pdf.

Flavin, P. (2012). Income inequality and policy representation in the American States. American Politics Research, 40(1), 29-59.

Flecker, J., Hentges, G., \& Balazs, G. (2007). Potentials of political subjectivity and the various approaches to the extreme right: Findings of the qualitative research. In J. Flecker (Ed.), Changing working Life and the appeal of the extreme right (pp. 35-62). Aldershot: Ashgate.

Franklin, M., Mackie, T., \& Valen, H. (Eds.). (1992). Electoral change: Responses to evolving social and attitudinal structures in Western Countries. Cambridge University Press: Cambridge.

Freire, A. (2004). Issue voting in Portugal: The 2002 legislative elections. West European Politics, 27(5), $779-800$.

Freire, A. (2006). Leftright context. Pax Méridionale, 25(2), 153-173.

Fuchs, D., \& Klingemann, H.-D. (1990). The left-right schema. In M. K. Jennings, et al. (Eds.), Continuities in political action: A longitudinal Study of Political Orientations in Three Western Democracies (pp. 203-238). Berlin: Walter de Gruyter.

Funke, M., Schularick, M., \& Trebesch, C. (2016). Going to extremes: Politics after financial crises, 1870-2014. European Economic Review, 88, 227-260. 
Furedi, F. (2002). Culture of Fear. Risk-taking and the morality of low expectations. London: Continuum.

Geishecker, I. \& Siedler, T. (2012). Job loss fears and (extremist) party identification: First evidence from panel data. SOEP papers on Multidisciplinary Panel Research 511.

Gerber, A. S., Huber, G. A., Doherty, D., Dowling, C. M., \& Ha, S. E. (2010). Personality and political attitudes: Relationships across issue domains and political contexts. American Political Science Review, 104(1), 111-133.

Giger, N., Rosset, J., \& Bernauer, J. (2012). The poor representation of the poor in a comparative perspective. Representation, 48(1), 47-61.

Gilens, M. (2009). Preference gaps and inequality in representation. Political Science \& Politics, 42(2), 335-341.

Groves, R. M. (2006). Nonresponse rates and nonresponse bias in Household Surveys. Public Opinion Quarterly, 70(5), 646-675.

Gunther, R., \& Montero, J. R. (2001). The anchors of partisanship: A comparative analysis of voting behaviour in four southern European countries. In N. Diamandouros \& R. Gunther (Eds.), Parties, Politics, and democracy in New Southern Europe (pp. 83-152). Baltimore: JHU Press.

Holm, A., \& Jæger, M. M. (2008). Does relative risk aversion explain educational inequality? A dynamic choice approach. Research in Social Stratification and Mobility, 26(3), 199-219.

Hooghe, L., Marks, G., \& Wilson, C. J. (2002). Does left/right structure party positions on European integration? Comparative Political Studies, 35(8), 965-989.

House of Commons (2015). The Parties' housing policy commitments 2015. Retrieved September 18, 2019, from https://researchbriefings.files.parliament.uk/documents/SN07142/SN07142.pdf.

Im, Z. J., Mayer, N., Palier, B., \& Rovny, J. (2019). The losers of digitalization: A reservoir of votes for the radical right? Research \& Politics, 6(1), 1-7.

Inglehart, R., \& Klingemann, H.-D. (1976). Party identification, ideological preference, and the leftright dimension among Western mass publics. In I. Budge, I. Crewe, \& D. Farlie (Eds.), Party identification and beyond: Representations of voting and party competition (pp. 243-273). London: Wiley.

Inglehart, R., \& Norris, P. (2003). Rising Tide: Gender equality and cultural change around the world. Cambridge: Cambridge University Press.

Jackman, R. W., \& Volpert, K. (1996). Conditions favoring parties of the extreme right in Western Europe. British Journal of Political Science, 26(4), 501-521.

Kahnemann, D., \& Tversky, A. (1979). Prospect Theory: An analysis of decision under risk. Econometrica, 47(2), 263-291.

Kitschelt, H. (1994). The Transformation of European social democracy. Cambridge: Cambridge University Press.

Kriesi, H., Grande, E., Lachat, R., Dolezal, M., Bornschier, S., \& Frey, T. (2006). Globalization and the transformation of the national political space: Six European countries compared. European Journal of Political Research, 45(6), 921-956.

Lengfeld, H. (2018). Eine Analyse der Ursachen der Parteiidentifikation mit der „Alternative für Deutschland" mit dem Sozio-oekonomischen Panel 2016. Zeitschrift für Soziologie, 47(3), 181-199.

Lipset, S. M. (1960). Political man: The social bases of politics. New York: Doubleday.

Lipset, S. M., \& Bendix, R. (1959). Social mobility in industrial society. Berkeley: University of California Press.

Lupton R, Heath N, Salter E (2009) Education priority. In: Hills J, Sefton T, Stewart K (eds), Towards a more. Policy Press, Bristol.

Margalit, M. (2013). Explaining social policy preferences: Evidence from the Great Recession. American Political Science Review, 107(1), 80-103.

Martinussen, W. (1992). Social mobility, meritocratic values, and political orientations in Norway. In F. C. Turner (Ed.), Social mobility and political attitudes: Comparative perspectives (pp. 103125). New Brunswick: Transaction Publishers.

Mols, F., \& Jetten, J. (2016). Explaining the appeal of populist right-wing parties in Times of economic prosperity. Political Psychology, 37(2), 275-292.

Mutz, D. C. (2018). Status threat, not economic hardship, explains the 2016 presidential vote. Proceedings of the National Academy of Science, 9, E4330-E4339.

Nai, A. (2018). Fear and worldwide. Journal of Political Marketing. https://doi.org/10.1080/15377 857.2018.1491439. 
Niemietz, K. (2012). Abundance of land, shortage of housing. IEA Discussion Paper No. 38, Institute of Economic Affairs, London.

Norris, P. (2005). Radical right: Voters and parties in the electoral market. New York: Cambridge University Press.

OECD (2019). Risks that Matter. Main Findings from the 2018 OECD Risks that Matter Survey. Retrieved September 18, 2019, from www.oecd.org/social/risks-that-matter.htm.

Peugny, C. (2007). La mobilité sociale descendante: l'épreuve du déclassement. PhD dissertation, Institut d'Études Politiques de Paris.

Pokorny, S. (2018). Von A wie Angst bis Z wie Zuversicht. Eine repräsentative Untersuchung zu Emotionen und politischen Einstellungen in Deutschland nach der Bundestagswahl 2017. Analysen \& Argumente, 302, 1-17.

Quattrone, G., \& Tversky, A. (1988). Contrasting rational and psychological analyses of political choice. The American Political Science Review, 82(3), 719-736.

Rainer, H., \& Siedler, T. (2007). Subjective income and employment expectations and preferences for redistribution. Economic Letters, 99(3), 449-453.

Ridout, T. N., \& Searles, K. (2011). It's my campaign I'll cry If I want to: How and when campaigns use emotional appeals. Political Psychology, 32(3), 439-458.

Rodrik, D. (2001). Why is there so much economic insecurity in Latin America? CEPAL Review, 73, 7-31.

Rueda, D., Stegmueller, D. \& Idema, T. (2014). The effects of Income Expectations on Redistributive Preferences in Western Europe. In Presented at the Annual Meeting of the American Political Science Association. Retrieved September 19, 2019, from https://users.ox.ac.uk/ polf0050/ RuedaStegmuellerIdema2014.pdf.

Rydgren, J. (2007). The sociology of the radical right. Annual Review of Sociology, 33, 241-262.

Salmela, M., \& von Scheve, C. (2017). Emotional roots of right-wing political populism. Social Science Information, 56(4), 567-595.

Schmitt, H., \& van der Eijk, C. (2009). On the changing and variable meaning of left and right: an analysis of MRG/CMP data and the findings of the postelection surveys of the European Voter database. Santiago de Chile: In Paper prepared for the presentation at the IPSA conference.

Schöneck, N. M., Mau, S., \& Schupp, J. (2011). Gefühlte Unsicherheit: Deprivationsängste und Abstiegssorgen der Bevölkerung in Deutschland. SOEPpapers, 428, 1-14.

Schuck, B., \& Shore, J. (2019). How intergenerational mobility shapes attitudes towards work and welfare. The Annals of the American Academy of Political and Social Science, 682(1), 139-154.

Simiti, M. (2016). Rage and protest: The case of the Greek indignant movement. Contention, 3(2), 33-50.

Social Mobility Commission (2016). State of the Nation 2016: Social Mobility in Great Britain. Report to the British Parliament pursuant to section 8B(6) of the Life Chances Act 2010. Retrieved September 18, 2019, from https://www.gov.uk/government/publications/state-of-thenation-2016.

Steenbergen, M. R., \& Siczek, T. (2017). Better the devil you know? Risk-taking, globalization and populism in Great Britain. European Union Politics, 18(1), 119-136.

Steenvoorden, E., \& Harteveld, E. (2018). The appeal of nostalgia: The influence of societal pessimism on support for populist radical right parties. Western European Politics, 41(1), 28-52.

Thijssen, L., \& Wolbers, M. H. J. (2016). Determinants of intergenerational downward mobility in the Netherlands. Social Indicators Research, 128(3), 995-1010.

Thorisdottir, H., Jost, J. T., Liviatan, I., \& Shrout, P. E. (2007). Psychological needs and values underlying left-right political orientation: Cross-national evidence from Eastern and Western Europe. Public Opinion Quarterly, 71(2), 175-203.

Tosun, J., Arco-Tirado, J. L., Caserta, M., Cemalcilar, Z., Freitag, M., \& Hörisch, F. (2019). Perceived economic self-sufficiency: A country- and generation-comparative approach. European Political Science, 18(3), 510-531.

United Nations. (2012). World Youth Report: Youth voice concern over employment prospects. New York: Department of Economic and Social Affairs, United Nations.

van de Werfhorst, H., \& Hofstede, S. (2007). Cultural capital or relative risk aversion? Two mechanisms for educational inequality compared. British Journal of Sociology, 58(3), 391-415.

Vegetti, F., \& Širinić, D. (2019). Left-right categorization and perceptions of party ideologies. Political Behavior, 41, 257-280. 
Visser, M., Lubbers, M., Kraaykamp, G., \& Jaspers, E. (2014). Support for radical left ideologies in Europe. European Journal of Political Research, 53(3), 541-558.

Wilensky, H. L., \& Edwards, H. (1959). The Skidder: Ideological adjustments of downward mobile workers. Sociological Review, 24(2), 215-231.

Zandonella, M. \& Perlot, F. (2017). Wahltagsbefragung und Wählerstromanalyse. Nationalratswahl 2017. SORA Institute for Social Research and Consulting, ISA Institut für Strategieanalysen. Retrieved September 18, 2019, from https://strategieanalysen.at/wp-content/uploads/2017/10/ ISA-SORA-Wahltagsbefragung-NRW2017-1.pdf.

Zechmeister, E. (2006). What's left and who's right? A Q-method study of individual and contextual influences on the meaning of ideological labels. Political Behavior, 28(2), 151-173.

Publisher's Note Springer Nature remains neutral with regard to jurisdictional claims in published maps and institutional affiliations. 